\title{
Evaluation of Long Term Performance for Initial Public Offerings (IPO) in Malaysia: A Fama-French Method
}

\author{
Nashirah Abu Bakar ${ }^{1}$, Sofian Rosbi \\ ${ }^{1}$ Islamic Business School, College of Business, Universiti Utara Malaysia, Kedah, Malaysia \\ ${ }^{2}$ School of Mechatronic Engineering, Universiti Malaysia Perlis, Malaysia
}

\begin{abstract}
:
The objective of this study is to evaluate performance of initial public offerings for 16 sharia compliant companies listed on the Malaysia Stock Exchange. Data of stock price are collected from Thomson Reuters Datastream for 36 months starting from January 2016 until December 2018. The method implemented is using Fama-French approach that evaluates expected return with three factors namely Market Risk Premium (MRP), Small Minus Big (SMB) and High Minus Low (HML). Result shows the abnormal return for 36 months is -3.399 which indicates negative value. The negative value of $y$-intercept gives interpretation that market (FTSE Bursa Malaysia KLCI) performed better than portfolio. The findings of this study will help investors to understand the financial dynamic behavior in Malaysia Stock Exchange. In addition, it will help investors to select appropriate financial assets for investment portfolio in gaining better return.
\end{abstract}

Keywords: Long Term Performance, Initial Public Offerings (IPO), Fama-French Model

\section{Introduction}

Initial public offering (IPO) literature has highlighted two anomalies that are underpricing of IPO (Abu Bakar and Rosbi, 2017; Chahine and Tohme, 2009; Islam, et al., 2010) and long term underperformance of IPO shares (Abu Bakar, et. al., 2019: Abu Bakar and Rosbi, 2016; Zarafat and Vejzagic, 2014). Underpricing is referring to the difference between the offer price and the closing price of the IPO shares on the first trading day (Loughran and Ritter, 2002; Ritter, 1991). Long term performance generally refers to the period below than 10 years, but most of the previous study investigates the 1 until 3 year shares price performance.

A body of literature found that IPO are underpriced. For instance, Islam, et al. (2010) found the level of IPO underprincing in Bangladesh was $480.72 \%$. Chahine and Tohme (2009) found the level of IPO underpricing in Middle East and North Africa was $184.1 \%$. Study that focus on the IPO shares performance in Malaysian Stock Exchange found IPO are underpriced at 21.22\% (Ammer and Ahmad-Zaluki, 2016). In contrast to the almost certain initial short term performance there is an average substantial underperformance of IPO shares over longer periods. Moreover, IPO shares are seems to underperform the market value. For instance Goergen et al., (2007) examines the long term performance of IPO in United Kingdom found that small company behave differently from large companies and suffer from worse long term performance than large companies. Drobetz et al. (2005) indicated that long term performance of Swiss IPO are underperformed their benchmarks. Kooli and Suret (2004) investigated long-term performance in Canada found that IPO are underperformed. While, study on the long term performance of IPO in Malaysian market found IPO are underperformed (Ahmad-Zaluki and Kect, 2012).

Therefore, the purpose of this study is to fill the gap in the literature by examine the long term performance of IPO for sharia compliant companies listed on the Malaysian Stock Exchange using a Fama-French three factors model. The unique feature of Malaysian Stock Exchange is due to provide two types of market known as sharia board and non-sharia board. Most of the previous studies are combines companies listed on the sharia board and non-sharia board. Thus, this study was selected sharia compliant companies only. This 
study contributes to the new insight of the long term performance of IPO for sharia compliant companies listed on the Malaysian Stock Exchange.

\section{Literature review}

A body of literature investigates the performances and returns of IPO shares and tends to indicate that companies are underpriced and underperform the market value (Carter et al., 1998; Lee, et al., 1996; Chi and Padgett, 2005; Heerden and Alagidede, 2012; Samarakoon, 2010; Ekkayokkaya and pengniti, 2012; Darmadi and Gunawan, 2012; Zhang and King, 2008; Agathee, et al., 2012; Borges, 2007. Varies methods are used in measuring the performance of shares prices. Previous study reported diversification is one of method that can be used in examine the performance of companies (Markowitz, 1952). Therefore, modern portfolio theory was developed in 1952 in order to analyze an expected rate of return that investors earn (Abu Bakar and Rosbi, 2018). In 1964, Sharpe was introduced Capital Asset Pricing Model (CAPM) in order to explain excess portfolio returns (Sharpe, 1964). The CAPM has been widely used for financial market analysis. Research involving the CAPM has included pricing risky assets, estimating the cost of equity, gauging portfolio performance, measuring abnormal returns, and calculating the number of futures contracts to sell for hedging the equity portfolio (Hwang, 2012).

Although CAPM has revolutionized the field of finance but various empirical tests have challenged this theory and revealed several drawbacks (Sattar, 2017). Therefore, Fama-French three factor model was developed as a response to inadequate performance of the CAPM. The Fama-French three-factor model suggests that the excess return on a broad market portfolio from the CAPM is not a complete explanation of the expected return on a portfolio in excess of the risk free rate (Black, 2006). Additionally, Fama-French three factors are developed to extend the CAPM model. The Fama-French model was added the value and small-cap stocks in order to outperform the markets value. By including these factors, the Fama-French three-factor model tends to outperforming which is thought to make a better tool for evaluating manager performance.

Fama-French model have been test in varies market. For instance Nartea, et al., (2009) test a Fama French method implement in New Zealand market. They found that Fama French model provided some improvement in explanatory power relative to the CAPM. Thus this study used Fama-French three factor model to evaluate the performance of IPO for sharia compliant companies in Malaysian market.

\section{Research methodology}

The purpose of this study is to analyze the performance of initial public offering for 36 months. In validating the findings, this study performed normality checking, regression analysis, model fit diagnostics test.

\subsection{Data selection}

The Fama-French model is implemented to analyze the performance for stock price of 16 companies that issued initial public offerings in year of 2014 and 2015. The 16 companies are sharia compliant companies that listed in Malaysia Stock Exchange. Table 1 shows list of selected companies that issued initial public offerings. This study collected stock price from database of Thomson Reuters Datastream. The market benchmark in this study is using FTSE Bursa Malaysia KLCI Index. Meanwhile risk-free rate is referring to Malaysian Treasury Bills (MTB).

Table 1: List of sharia compliant companies issued IPO in year of 2014 and 2015

\begin{tabular}{|c|l|c|}
\hline No. & \multicolumn{1}{|c|}{ Companies } & Year of IPO issued \\
\hline 1 & BIOALPHA HOLDINGS BERHAD & 2015 \\
\hline 2 & MALAKOFF CORPORATION BERHAD & 2015 \\
\hline 3 & DOLPHIN INTERNATIONAL BERHAD & 2015 \\
\hline 4 & XIN HWA HOLDINGS BERHAD & 2015 \\
\hline
\end{tabular}




\begin{tabular}{|c|l|c|}
\hline 5 & IKHMAS JAYA GROUP BERHAD & 2015 \\
\hline 6 & SUNWAY CONSTRUCTION GROUP BERHAD & 2015 \\
\hline 7 & AEMULUS HOLDINGS BERHAD & 2015 \\
\hline 8 & AL-SALAM REAL ESTATE INVESTMENT TRUST & 2015 \\
\hline 9 & IOI PROPERTIES GROUP BERHAD & 2014 \\
\hline 10 & ICON OFFSHORE BERHAD & 2014 \\
\hline 11 & BOUSTEAD PLANTATIONS BHD & 2014 \\
\hline 12 & ECONPILE HOLDINGS BHD & 2014 \\
\hline 13 & SASBADI HOLDINGS BHD & 2014 \\
\hline 14 & CARIMIN PETROLEUM BERHAD & 2014 \\
\hline 15 & E.A.TECHNIQUE (M) BERHAD & 2014 \\
\hline 16 & KRONOLOGI ASIA BERHAD & 2014 \\
\hline
\end{tabular}

\subsection{Monthly return calculation}

This study calculated the monthly return for particular month $t$ using Equation (1).

$R_{i, t}=\left(\frac{M P_{t}-M P_{t-1}}{M P_{t-1}}\right) \times 100 \%$

In Equation (1), the variables are defined as below:

$R_{i, t}:$ Return for company $i$ in month $t$,

$M P_{t}$ : Average monthly share price for particular month $t$, and

$M P_{t-1}$ : Average monthly share price for particular month $t-1$.

\subsection{Procedure of Fama-French calculation}

The mathematical representation of the Fama-French model is described in Equation (2).

$R_{p t}-R_{f t}=\alpha_{p}+\beta_{p}\left(R_{m t}-R_{f t}\right)+\gamma_{p}(\mathrm{SMB})+\delta_{p}(\mathrm{HML})+\varepsilon_{p t}$

In Equation (2), the parameters are described as below:

$R_{p t}$ : Monthly return on IPO portfolio,

$R_{f t}:$ Treasury bill rate

$R_{m t}$ : Monthly market return

$R_{m t}-R_{f t}:$ Market risk premium (MRP),

SMB (Small Minus Big): Historic excess returns of small-cap companies over large-cap companies,

HML (High Minus Low) : Historic excess returns of values stocks (high book-to-price ratio) over growth stocks (low book-to-price ratio)

$\alpha_{p}$ : Intercept that indicates the performance of average monthly abnormal return.

In the Fama-French model, positive $\alpha_{p}$ indicates the market performs better than portfolio selection. Meanwhile, negative $\alpha_{p}$ indicates the portfolio performs better than market. 


\subsection{Model fit diagnostics checking}

In validating the regression analysis findings, three statistical tests are performed. The three statistical tests are R-squared analysis, autocorrelation and multi-collinearity test.

The first statistical test for model fit is R-squared. The R-squared is a statistical measure of how close data are to fitted regression line. It is also known as coefficient of determination, or coefficient of multiple determinations for multiple regressions. The definition of R-squared is percentage of the response variable variation that is explained by a linear model.

$$
\text { R-squared }=\frac{\text { Explained variation }}{\text { Total variation }}
$$

The value of R-squared is always between 0 and $100 \%$. The value of $0 \%$ indicates that model explains none of the variability of the response data around its mean. The value of $100 \%$ indicates that model explains all the variability of the response data around its mean. The higher value of R-squared, the better the model fits to data.

The second statistical test for model validity is Durbin-Watson test. In statistics, the Durbin-Watson statistic is a test statistic used to detect the presence of autocorrelation at lag 1 in the residuals (prediction errors) from a regression analysis. The Durbin-Watson test statistic applied to evaluate the residuals from least squares regressions, and developed bounds tests for the null hypothesis that the errors are serially uncorrelated against the alternative that they follow a first order autoregressive process.

The Durbin-Watson test is described by Equation (4).

$$
d=\frac{\sum_{t=2}^{T}\left(e_{t}-e_{t-1}\right)^{2}}{\sum_{t=1}^{T} e_{t}^{2}}
$$

In Equation (4), the parameters are described as follow:

$e_{t}$ : The residual associated with the observation at time $t$,

$e_{t-1}$ : The residual associated with the observation at time $t-1$,

$\mathrm{T}$ : The number of observations, and

$d$ : The value of $d$ is approximately equal to $2(1-\mathrm{r})$, where $\mathrm{r}$ is the sample autocorrelation of the residuals. Value of $d$ should be between 1.5 and 2.5 that indicates data is not auto-correlated.

The third statistical test for model validity is variance inflation factor (VIF). The variance inflation factor is a measure of amount of multi-collinearity in a set of multiple regression variables. Variance inflation factor measures level of the behavior (variance) of an independent variable is influenced by its interaction with the other independent variables.

The equation of variance inflation factor can be illustrated as Equation (5).

$$
\mathrm{VIF}_{i}=\frac{1}{1-R_{i}^{2}}
$$

In Equation (5), the variables are described as follow:

$\mathrm{VIF}_{i}$ : Variance inflation factor (VIF) for $X_{i}$.

$R_{i}^{2}$ : The coefficient of determination of the regression equation with $X_{i}$ on the left hand side, and all other predictor variables (all the other $X$ variables) on the right hand side. 
The magnitude of multi-collinearity is evaluated by considering the size of the VIF. If value of VIF is larger than 10, it indicates the variables suffers high multi-collinearity.

\section{Result and discussion}

The objective of this study is to evaluate the long term performance of initial public offerings using FamaFrench three factors method. Therefore, this study performed normality checking dependent variables and independent variables, multiple regression analysis for Fama-French three factors model, model fit diagnostics checking and collinearity testing.

\subsection{Normality checking for dependent variable}

In evaluating the long term performance of initial public offering, this study selected the independent variable as expected return with benchmarked to risk free rate. Figure 1 shows the monthly data of expected return with benchmarked risk free rate for 16 sharia compliant companies. The observation periods in this analysis is involving 36 monthly observations. The independent variable is calculated as average from 16 companies of monthly return with benchmark to Malaysian Treasury Bills (MTB). The value of expected return for first month observations is $-4.01 \%$ on January 2016. Meanwhile, the value for last observation $\left(36^{\text {th }}\right.$ month observation on December 2018 ) is $-15.36 \%$. The maximum value is $5.40 \%$ on January 2017 $\left(13^{\text {th }}\right.$ month observation).

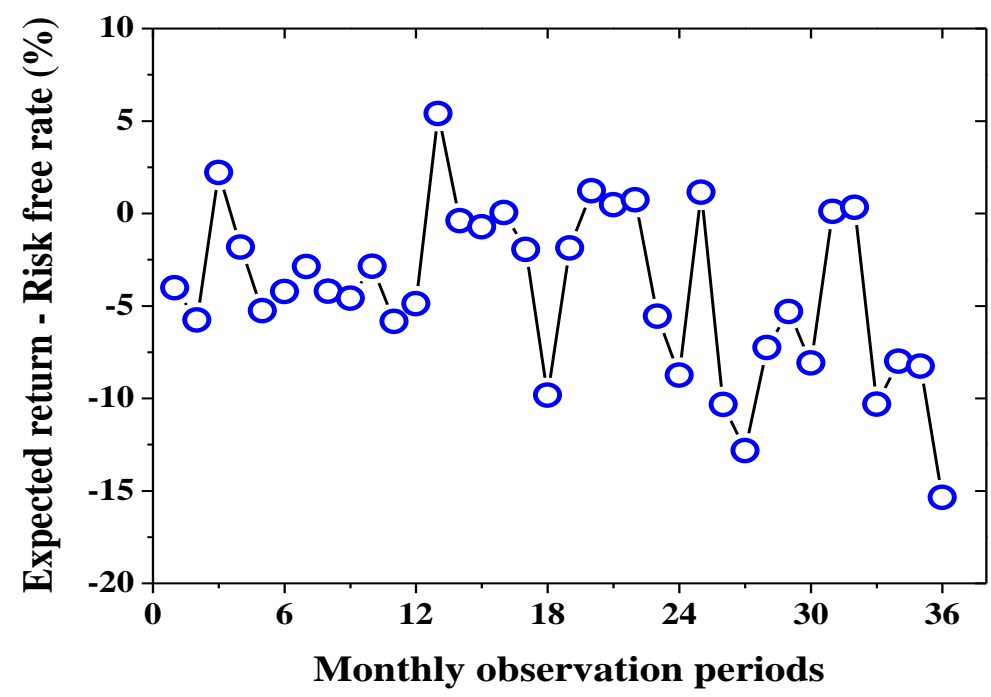

Figure 1: Average expected return with benchmark to Malaysian Treasury Bills

Next, this study performed normality for expected return with benchmarked to risk free rate. Figure 2 shows histogram of average expected return with benchmark to Malaysian Treasury Bills. Red line indicates normal distribution line. Return rate data distributed closely to normal distribution line. Therefore, data distribution of return rate follows normal distribution.

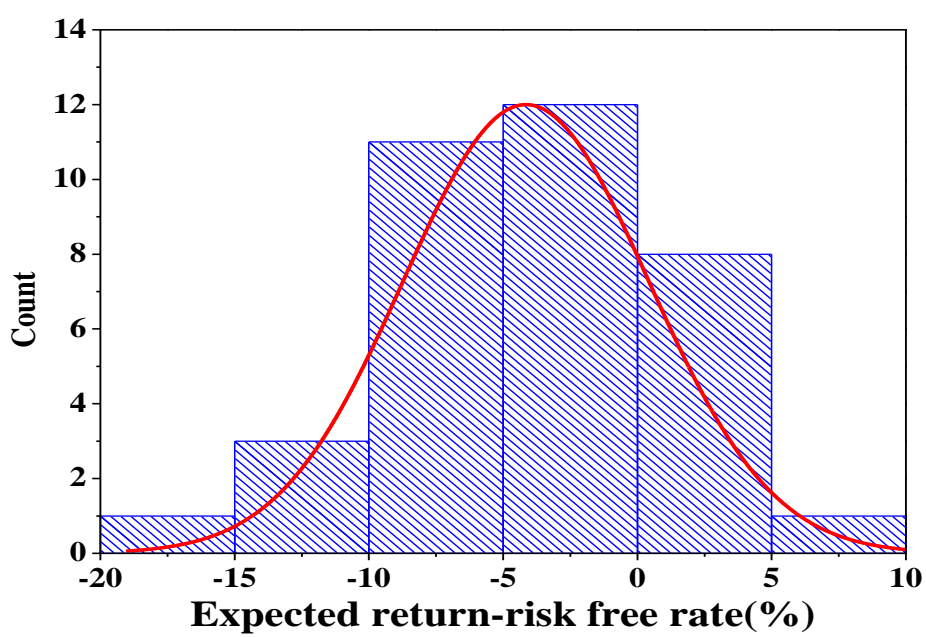

Figure 2: Histogram of average expected return with benchmark to Malaysian Treasury Bills 
Next, this study validated the normality of data distribution using statistical test. The number of return rate data is 36. Therefore, the appropriate statistical test is Shapiro-Wilk normality test. Table 2 shows ShapiroWilk normality test and descriptive statistics for average expected return with benchmark of risk free rate. Shapiro-Wilk test indicates the significant value is 0.825 is larger than 0.05 . Therefore, the data distribution is follow normal distribution pattern. In the same time, descriptive statistics indicates mean of return is -4.15 $\%$ and standard deviation is 4.58 . Therefore, independent variable is valid for multiple regression analysis.

Table 2: Shapiro-Wilk normality test and descriptive statistics for return

\begin{tabular}{|c|c|c|}
\hline \multicolumn{3}{|c|}{ Shapiro-Wilk normality test } \\
\hline Statistic & Degree of freedom, df & Significant value (p-value) \\
\hline 0.982 & 36 & 0.825 \\
\hline \multicolumn{2}{|c|}{ Descriptive statistics for return } \\
\hline \multicolumn{2}{|c|}{ Mean } & $-4.15 \%$ \\
\hline \multicolumn{2}{|c|}{ Standard deviation } & 4.58 \\
\hline
\end{tabular}

\subsection{Normality checking for independent variable}

Then, this study analyzed the normality of data distribution for three independent variables including descriptive statistics. Table 3 shows Shapiro-Wilk normality test and descriptive statistics for three independent variables namely market risk premium, small minus big, and high minus low.

Table 3 shows value for mean of market risk premium is $-2.83 \%$ and standard deviation is 1.97 . The significant value for market risk is 0.996 larger than 0.05 . Therefore, data distribution for independent variable namely market risk premium is follows normal distribution.

Table 3 shows value for average return of small minus big (SMB) is $-0.01 \%$ and standard deviation is 4.78 . The significant value for market risk is 0.191 larger than 0.05 . Therefore, data distribution for independent variable namely average return for small minus big is follows normal distribution.

Table 3 shows value for average return of high minus low (HML) is $1.14 \%$ and standard deviation is 4.29. The significant value for market risk is 0.377 larger than 0.05 . Therefore, data distribution for independent variable namely average return for high minus low is follows normal distribution.

Table 3 indicates significant value of Shapiro-Wilk normality test for three variables is larger than 0.05 . This indicates this study failed to reject null hypothesis of Shapiro-Wilk normality test. As the conclusion, data distributions for all three independent variables follow normal distribution. This assumption is important to indicate all independents variables are valid for multiple regression method.

Table 3: Shapiro-Wilk normality test and descriptive statistics for independent variables

\begin{tabular}{|c|c|c|c|c|c|c|}
\hline & \multicolumn{2}{|c|}{ Descriptive statistics } & \multicolumn{4}{|c|}{ Shapiro-Wilk normality test } \\
\hline Variable & Mean & $\begin{array}{c}\text { Standard } \\
\text { deviation }\end{array}$ & Statistic & $\begin{array}{c}\text { Degree of } \\
\text { freedom, df }\end{array}$ & $\begin{array}{c}\text { Significant } \\
\text { value }\end{array}$ & $\begin{array}{c}\text { Normality } \\
\text { distribution }\end{array}$ \\
\hline $\begin{array}{c}\text { Market risk } \\
\text { premium }\end{array}$ & $-2.83 \%$ & 1.97 & 0.992 & 36 & 0.996 & Normal \\
\hline $\begin{array}{c}\text { Small minus big } \\
\text { (SMB) }\end{array}$ & $-0.01 \%$ & 4.78 & 0.958 & 36 & 0.191 & Normal \\
\hline $\begin{array}{c}\text { High minus low } \\
\text { (HML) }\end{array}$ & $1.14 \%$ & 4.29 & 0.968 & 36 & 0.377 & Normal \\
\hline
\end{tabular}




\subsection{Multiple regression analysis for Fama-French method}

In performing Fama-French method to evaluate the long term performance of initial public offering, the correlation among outcome variable (independent variable) and predictors (independent variables) need to performed.

Table 4 shows Pearson correlation test between dependent variable (expected excess return) with three independent variables namely market risk premium (MRP), small minus big (SMB) and high minus low (HML). The correlation between expected excess return with market risk premium is 0.282 . The significant value is 0.096 less than 0.1 level of significant. Therefore, there is significant and weak positive correlation between market risk premium and expected excess return.

In addition, Table 4 indicates correlation between expected excess return with small minus big (SMB) is 0.286 . The significant value is 0.091 less than 0.1 level of significant. Therefore, there is significant and weak positive correlation between small minus big with expected excess return.

Next, Table 4 indicates correlation between expected excess return with high minus low (HML) is 0.564. The significant value is 0.000 less than 0.05 level of significant. Therefore, there is significant and moderate positive correlation between high minus low with expected excess return.

Table 4: Pearson correlation analysis between dependent variable and independent variables

\begin{tabular}{|c|c|c|c|}
\hline Dependent variable & \multicolumn{3}{|c|}{ Independent variables } \\
\hline $\begin{array}{c}\text { Expected excess return } \\
\text { (Return-risk free rate) }\end{array}$ & $\begin{array}{c}\text { Market risk } \\
\text { premium }\end{array}$ & $\begin{array}{c}\text { Small minus big } \\
\text {, SMB }\end{array}$ & $\begin{array}{c}\text { High minus low, } \\
\text { HML }\end{array}$ \\
\hline $\begin{array}{c}\text { Pearson correlation with } \\
\text { dependent variable }\end{array}$ & 0.282 & 0.286 & 0.564 \\
\hline $\begin{array}{c}\text { Significant value } \\
\text { (p-value) }\end{array}$ & 0.096 & 0.091 & 0.000 \\
\hline
\end{tabular}

Then, this study performed regression analysis to evaluate the coefficient in Fama-French model. Table 5 shows coefficient of regression analysis for Fama-French model. Therefore, Fama-French model can model as Equation (6).

Expected excess return $=-3.399+0.497($ Market Risk $)+0.328(\mathrm{SMB})+0.581(\mathrm{HML})$

Table 5 indicates the constant, small minus big (SMB) and high minus low (HML) are significant variables. Meanwhile, market risk premium is not significant. In addition, constant value is -3.399 which indicates negative value. The negative value of y-intercept gives interpretation that market (FTSE Bursa Malaysia KLCI) performed better than portfolio.

Table 5: Coefficient of regression analysis for Fama-French model

(Dependent variable is expected excess return)

\begin{tabular}{|l|l|l|l|}
\hline Model & Coefficient & t-statistics & Significant value \\
\hline $\begin{array}{l}\text { Constant } \\
\text { (y-intercept) }\end{array}$ & -3.399 & -3.139 & 0.004 \\
\hline Market risk premium & 0.497 & 1.620 & 0.115 \\
\hline Small minus big, SMB & 0.328 & 2.633 & 0.013 \\
\hline High minus low, HML & 0.581 & 4.132 & 0.000 \\
\hline
\end{tabular}

\subsection{Model diagnostics statistical tes}


In this section, this study evaluates the statistical fit of model using Durbin Watson model. Table 6 shows statistical test for fitness of regression model. The R-squared $\left(\mathrm{R}^{2}\right)$ value is 0.466 that indicates model explains $46.67 \%$ of the variability of the response data around its mean. The value of R-squared indicates $46.6 \%$ of variance in the dependent variable (average excess return) which can be explained by the independent variables (Market risk premium, SMB, HML).

Next, the Durbin-Watson is a test statistic used to detect the presence of autocorrelation at lags one in the residuals (prediction errors) from a regression analysis. Table 6 shows the Durbin Watson value is 1.609. This value is between range of 1.5 and 2.5 that indicates there is no autocorrelation.

Then, Table 6 indicates the F-value is 9.293 with significant value is 0.000 . The significant value is less than 0.05 that indicates this study reject the null hypothesis of F-test. Therefore, F-test indicates the regression model provides a better fit than the intercept-only model.

Table 6: Model fit statistical test

\begin{tabular}{|l|c|}
\hline \multicolumn{2}{|c|}{ Model fit test } \\
\hline R-squared & 0.466 \\
\hline Durbin Watson & 1.609 \\
\hline F-value & 9.293 \\
\hline Significant & 0.000 \\
\hline
\end{tabular}

Next, Table 7 shows collinearity diagnostics for regression model. Table 7 shows condition index for dimension 1, 2, 3 and 4 is less than 15. Therefore, there is no multi-collinearity in the regression model. As a conclusion, the regression model is a valid model.

This study also validated the multi-collinearity finding by another statistical test using variance inflation factor (VIF). The VIF value provides an index that measures how much variance of an estimated regression coefficient is increased because of collinearity. Table 8 shows the VIF value for each of independent variables. All of VIF values are in the range of 1 to 10 that indicates there is no multi-collinearity. As a conclusion, the regression model is reliable and valid.

Table 7 : Collinearity diagnostics

\begin{tabular}{|c|c|c|c|c|c|c|c|}
\hline \multirow{2}{*}{ Model } & \multirow{2}{*}{ Dimension } & \multirow{2}{*}{ Eigenvalue } & \multirow{2}{*}{$\begin{array}{c}\text { Condition } \\
\text { Index }\end{array}$} & \multicolumn{4}{|c|}{ Variance Proportions } \\
\cline { 5 - 8 } & & & (Constant) & MRP & SMB & HML \\
\hline \multirow{2}{*}{1} & 1 & 1.901 & 1.000 & .07 & .07 & .00 & .04 \\
\cline { 5 - 8 } & 2 & 1.051 & 1.345 & .00 & .01 & .65 & .24 \\
\cline { 2 - 8 } & 3 & .889 & 1.462 & .00 & .02 & .34 & .63 \\
\cline { 2 - 8 } & 4 & .160 & 3.447 & .92 & .90 & .01 & .09 \\
\hline
\end{tabular}

a. Dependent Variable: return

Table 8: Variation inflation factor (VIF) analysis

\begin{tabular}{|l|c|c|}
\hline \multirow{2}{*}{ Model } & \multicolumn{2}{|c|}{ Collinearity Statistics } \\
\cline { 2 - 3 } & Tolerance & Variance Inflation factor (VIF) \\
\hline Market Risk Premium(MRP) & 0.954 & 1.048 \\
\hline Small Minus Big (SMB) & 0.987 & 1.013 \\
\hline High Minus Low(HML) & 0.961 & 1.040 \\
\hline
\end{tabular}




\section{Conclusion}

The objective of this study is to evaluate long term performance of initial public offerings using FamaFrench model. This study selected 16 sharia compliant companies that issued initial public offerings in year of 2014 and 2015.Main findings of this study are:

(a) Data distribution of average excess return (average return - risk free rate) is follows normal distribution. The descriptive statistics indicates mean of return is $-4.15 \%$ and standard deviation is 4.58 .

(b) In addition, data distributions for all three independent variables follow normal distribution. This assumption is important to indicate all independents variables are valid for multiple regression method.

(c) The regression analysis of data in this study can be model using Fama-French model in next equation. Expected excess return $=-3.399+0.497($ Market Risk $)+0.328(\mathrm{SMB})+0.581(\mathrm{HML})$

(d) The constant value (y-intercept) is -3.399 which indicates negative value. The negative value of $y$ intercept gives interpretation that market (FTSE Bursa Malaysia KLCI) performed better than portfolio.

(d) The R-squared $\left(\mathrm{R}^{2}\right)$ value is 0.466 that indicates model explains $46.67 \%$ of the variability of the response data around its mean. The value of R-squared indicates $46.6 \%$ of variance in the dependent variable (average excess return) which can be explained by the independent variables (Market risk premium, SMB, HML).

(e) The Durbin-Watson is a test statistic used to detect the presence of autocorrelation at lags one in the residuals (prediction errors) from a regression analysis. Result indicates Durbin Watson value is 1.609. This value is between range of 1.5 and 2.5 that indicates there is no autocorrelation.

(f) All of VIF values are in the range of 1 to 10 that indicates there is no multi-collinearity. As a conclusion, the regression model is sufficient and valid.

\section{References}

[1] Abu Bakar, N., Rosbi, S. and Uzaki, K. (2019). Evaluation of Long Term Performance for Initial Public Offerings using Market Adjusted Cumulative Abnormal Returns (MACAR): A Case Study of Islamic Finance in Malaysia. International Journal of Advances in Scientific Research and Engineering, 5(1), 51-58.

[2] Abu Bakar, N. and Rosbi, S. (2018). Efficient frontier analysis for portfolio investment in Malaysia stock market. Science International, 30(5), 723-729.

[3] Abu Bakar, N. and Rosbi, S. (2017). Impact of the Corporate Structure and Sharia-Compliant Status to Average Degree of IPO Underpricing in Malaysia Market. Advanced Science Letters, 23(9), 87588761.

[4] Abu Bakar, N. and Rosbi, S. (2016). Long Term Performance of Islamic Share Price for Initial Public Offerings (IPOs) in Malaysia: Evidence from Sharia-Compliant Companies Listed on the Malaysian Stock Exchange (2006-2010). International Journal of Management Science and Business Administration, 2(6), 55-66.

[5]Agathee, U.S., Sannassee, R.V. and Brooks, C. (2012). The underpricing of IPOs on the Stock Exchange of Mauritius. Research in International Business and Finance, 26(2), 281-303.

[6]Ahmad-Zaluki, N.A. and Kect, L.B. (2012). The investment performance of MESDAQ market initial public offerings (IPOS). Asian Academy of Management Journal of Accounting and Finance, 8(1), 123.

[7]Ammer, M. A. and Ahmad-Zaluki, N.A. (2016). The effect of underwriter's market share, spread and management earnings forecasts bias and accuracy on underpricing of Malaysian IPOs. International Journal of Managerial Finance, 12(3), 351-371.

[8]Black, A. J. (2006). Macroeconomic risk and the Fama-French three-factor model. Managerial Finance, 32(6), 505-517.

[9]Borges, M.R. (2006). Underpricing of Initial Public Offerings: The Case of Portugal. International Advances in Economic Research, 13(1), 65-80. 
[10] Carter, R.B., Dark, F.H. and Singh, A.K. (1998). Underwriter Reputation, Initial Return and LongRun Performance of IPO stocks. The Journal of Finance, 53(1), 283-311.

[11] Chahine, S. and Tohme, N.S. (2009). Is CEO Duality Always Negative? A Exploration of CEO Duality and Ownership Structure in the Arab IPO Context. Corporate Governance: An International Review, 17(2), 123-141.

[12] Chi, J. and Padgett, C. (2005). Short-run underpricing and its characteristics in Chinese initial public offering (IPO) markets. Research in International Business and Finance, 19(1), 71-93.

[13] Darmadi, S. and Gunawan, R. (2013). Underpricing, board structure, and ownership: An empirical examination of Indonesian IPO firms. Managerial Finance, 39(2), 181-200.

[14] Drobetz, W., Kammermann, M. and Walchli, U. (2005) Performance of Initial Public Offerings: The Evidence for Switzerland, Schmalenbach Business Review, 57 (3), 253-275.

[15] Ekkayokkaya M. and Pengniti, T. (2012) Governance reform and IPO underpricing. Journal of Corporate Finance, 18(2), 238-253.

[16] Goergen, M., Khurshed, A. and Mudambi, R. (2007) The long-run performance of UK IPOs: can it be predicted?. Managerial Finance, 33(6), 401-419.

[17] Heerden, G.V. and Alagidede, P. (2012). Short run underpricing of initial public offerings (IPOs) in the Johannesburg Stock Exchange (JSE). Review of Development Finance, 2, 130-138.

[18] Hwang, T., Gao, S. and Owen, H. (2012). A two-pass model study of the CAPM: Evidence from the UK stock market. Studies in Economics and Finance, 29(2), 89-104.

[19] Islam, A., Ali, R. and Ahmad, Z. (2010). An Empirical Investigation of the Underpricing of Initial Public Offerings in the Chittagong Stock Exchange. International Journal of Economics and Finance, 2(4), 36-46.

[20] Kooli, M. and Suret, J. (2004). The aftermarket performance of initial public offerings in Canada. Journal of Financial Management, 14, 47-66.

[21] Lee, P. J., Taylor, S. L. and Walter, T.S. (1996). Australian IPO pricing in the short and long run. Journal of Banking and Finance, 20, 1189-1210.

[22] Loughran, T. and Ritter, J.Y. (2004). Why Has IPO Underpricing Changed Over Time?. Financial Management, 33(3), 5-37.

[23] Markowitz, H. (1952). Portfolio Selection. Journal of Finance, 7(1), 77-91.

[24] Nartea, G.V., Ward, B.D. and Djajadikerta, H.G. (2009) Size, BM, and momentum effects and the robustness of the Fama-French three-factor model: Evidence from New Zealand. International Journal of Managerial Finance, 5(2), 79-200.

[25] Ritter, J.R. (1991). The Long Run Performance of Initial Public Offerings. Journal of Finance, 46(1):3-27.

[26] Samarakon, L.P. (2010). The Short-Run Underpricing of Initial Public Offerings in the Sri Lakan Stock Market. Journal of Multinational Financial Management, 20, 197-213.

[27] Sattar, M. (2017). CAPM Vs Fama-French Three-Factor Model: An Evaluation of Effectiveness in Explaining Excess Return in Dhaka Stock Exchange. International Journal of Business and Management, 12(5), 119-129.

[28] Sharpe, W. (1964) Capital Asset Prices: A Theory of Market Equilibrium. Journal of Finance, 19, 425-442.

[29] Zarafat, H. and Vejzagic, M. (2014). The Long-Term Performance of Initial Public Offerings: Evidence from Bursa Malaysia. Journal of Applied Economics and Business Research, 4(1):42-51.

[30] Zhang (Xinde), C. and King, T.H.D. (2008). The Decision to Cross-List: The Case of Chinese IPOs and ADRs. SSRN Electronic Journal. 